\title{
NOTE
}

\section{Isolation of Aeromonas salmonicida from salmon lice Lepeophtheirus salmonis and marine plankton}

\author{
Lars Nese ${ }^{1}$, Øivind Enger ${ }^{2, *}$ \\ ${ }^{1}$ University of Bergen, Department of Fisheries and Marine Biology, Bergen High Technology Center, N-5020 Bergen, Norway \\ ${ }^{2}$ University of Bergen, Department oi Microbiology and Plant Physiology, Jahnebakken 5, N-5007 Bergen, Norway
}

\begin{abstract}
Aeromonas salmonicida was isolated from salmon lice Lepeophtheirus salmonis and zooplankton in samples taken at a fish farm with an outbreak of furunculosis. Approximately $10^{4}$ cells of $A$. salmonicida per salmon louse and 600 cells of $A$. salmonicida per ml of homogenized plankton suspension were detected. By use of immunomagnetic beads coated with monoclonal antibodies against the lipopolysaccharides of $A$. salmonicida, the bacteria were retrieved in almost pure culture from certain of the heavily 'contaminated' environmental samples.
\end{abstract}

Aeromonas salmonicida, the etiological agent of furunculosis, causes severe losses in cultured fish in many parts of the world (Austin \& Austin 1987). Since 1985, furunculosis has spread epizootically in Norway. Furunculosis has now been recorded in most fish farms on the western coast of Norway, where outbreaks result in the highest mortalities experienced on the farms.

The survival potential of Aeromonas salmonicida in water has been thoroughly investigated (McCarthy 1977, Sakai 1986, Rose et al. 1990). The bacterium has never been isolated from any environmental sources but it has been detected in high numbers by application of immunofluorescence in samples from sediments, seawater, and surface films from fish farms stocked with salmon suffering from furunculosis (Enger \& Thorsen 1992).

Although fish have been regarded as the main vector in the transmission of furunculosis, ectoparasites may also serve as vectors because they have been shown to be likely vectors in the transfer of viral diseases (Ahne 1985, Mulcahy et al. 1990). Salmon lice may therefore

- Addressee for correspondence be important in introducing pathogens such as Aeromonas salmonicida into fish farms (Cusack \& Cone 1986, Nylund et al. 1991).

In this study we report immunofluorescence detection of Aeromonas salmonicida in high numbers in sediments, seawater, and in surface films. In addition, we have been able to isolate the bacterium from salmon lice and from marine plankton. We also discuss the benefits that immunomagnetic beads provide in the isolation of $A$. salmonicida from environmental samples.

Materials and methods. Sampling: Atlantic salmon Salmo salar suffering from furunculosis were killed by a blow to the head. Salmon lice were picked from the fish with sterile tweezers, care being taken not to collect lice from bloody areas on the fish. Plankton samples were collected by dragging a plankton trawl (mesh size $40 \mu \mathrm{m}$ ) through the upper $50 \mathrm{~cm}$ in a netcage. The samples were kept in the dark and on ice until they were processed in the laboratory on the same day. Water and sediments were sampled and processed as described by Enger \& Thorsen (1992).

Antibodies: Two monoclonal antibodies, AL2E6 and AL1B2, directed towards the lipopolysaccharide (LPS) and the outer protein layer (A-layer), respectively, of Aeromonas salmonicida were kindly donated by R. Nilsen, Apothekerenes Laboratorium, Tromsø, Norway.

Double staining of samples: The abundance of Aeromonas salmonicida and a total count in the samples were obtained by a combination of a fluorescent antibody technique (FA) and staining of bacterial DNA by 4',6-diamidino-2-phenylindole (DAPI) (Enger et al. 
1989). This method allows simultaneous enumeration of total number of bacteria and number of fluorescent antibody-stained cells in the same sample.

Fifteen $\mathrm{ml}$ of surface sample, $20 \mathrm{ml}$ of water samples, $1 \mathrm{ml}$ of plankton sample or $1 \mathrm{ml}$ of a 1:1000 dilution of sediment were filtered through Nuclepore filters with a pore size of $0.2 \mu \mathrm{m}$. The monoclonal antibody directed against the LPS of Aeromonas salmonicida (AL2E6) was used in the immunofluorescence assay.

Immunomagnetic beads: Monodispersed latex beads, $2.8 \mu \mathrm{m}$ in diameter, with covalently linked sheep anti-mouse IgG antibodies (Dynabeads, M-280 sheep anti-mouse IgG, Dynal A/S Oslo, Norway) were used in the experiment by following the manufacturer's instructions.

To coat the beads with mouse antibodies specific to Aeromonas salmonicida, about $10^{9}$ beads were transferred to a tube containing $12 \mathrm{ml}$ of monoclonal antibody preparation [anti-LPS diluted 1:500 in phosphate-

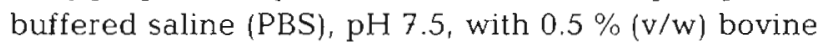
serum albumin (BSA) (Sigma Chemical Co., St. Louis, MO, USA)] (PBS-BSA). The beads were incubated with the monoclonal antibodies overnight at 5 to $7^{\circ} \mathrm{C}$ on an end-over-end rotator ( $4 \mathrm{rpm}$ ) to avoid settling. After the immunomagnetic beads had been drawn towards the inner wall of the tube by a magnet, the residual liquid was aspirated and the immunomagnetic beads were suspended in $5 \mathrm{ml}$ of sterile PBS-BSA.

Sample preparation: Salmon lice were counted and homogenized (Thommas Tissue Grinders, 3431-E04, Swedesboro, NJ, USA) in sterile physiological saline $(0.9 \% \mathrm{NaCl})$. One $\mathrm{ml}$ of the suspension was incubated with immunomagnetic beads $\left(2 \times 10^{8}\right.$ beads sample $\left.{ }^{-1}\right)$ for $1 \mathrm{~h}$. To remove unbound bacteria, the immunomagnetic beads were washed 5 times $11 \mathrm{ml}$ of physiological saline containing $0.1 \%$ Tween 20 ). Three replicate samples of $0.1 \mathrm{ml}$ of the bead suspension were trans- ferred to agar plates [Brain Heart Infusion Broth (Oxoid) $+1.5 \%$ agar (Difco) with $0.01 \mathrm{mg} \mathrm{ml}^{-1}$ Coomassie Brilliant Blue (Serva) and $0.015 \mathrm{mg}$ Oleandomycin (Oxoid) $\mathrm{ml}^{-1}$ (BHIA-CBB Ol 15)]. Colonies were counted after 48 h of incubation at $21^{\circ} \mathrm{C}$.

Surface sterilization of the salmon lice was carried out by dipping them twice in $70 \%$ ethanol. Between the dips the lice were washed in sterile physiological saline.

Plankton samples of $3 \mathrm{ml}$ were centrifuged $(90 \times g$ for $5 \mathrm{~min}$ ) and the supernatants were removed. The centrifuged plankton samples (ca $1 \mathrm{ml}$ ) were homogenized in $1 \mathrm{ml}$ of physiological saline and then incubated with immunomagnetic beads for $1 \mathrm{~h}$. The samples were then washed and inoculated on agar plates as described earlier.

Immuno-colony-blot: Aeromonas salmonicida was identified by the technique described by Rodrigue et al. (1989). Nitrocellulose membranes (BioRad, Richmond, CA, USA) were deposited on BHIA-CBB plates containing possible $A$. salmonicida colonies. The membranes were removed and treated with an antibody solution (AL1B2, diluted 1:4000) followed by an incubation with peroxidase-conjugated goat antimouse antibodies (BioRad, diluted 1:2000). After incubation with peroxidase substrate $(0.06 \% 4$-chloronaphthanol (BioRad) with $20 \%$ ethanol and $0.015 \%$ $\mathrm{H}_{2} \mathrm{O}_{2}$ in tris-buffered saline $(20 \mathrm{mM}$ Tris, $0.5 \mathrm{M} \mathrm{NaCl}$, $\mathrm{pH}=7.5$ ) colonies of $A$. salmonicida was observed as purple spots on the membranes.

Results and discussion. Fluorescent antibody detection showed that Aeromonas salmonicida comprised approximately 0.1 and $0.02 \%$ of the total bacterial numbers in the water samples and in the sediment, respectively (Table 1). The high number of $A$. salmonicida found in the sediment (Table 1) suggests that

Table 1. Aeromonas salmonicida. Number of bacteria detected using different detection methods. The samples were collected in a fish farm during an outbreak of furunculosis. Total: total bacterial counts after staining with DAPI. FA: counts with the fluorescent antibody technique. IMB: immunomagnetic beads. ND: not determined

\begin{tabular}{|c|c|c|c|c|c|c|c|}
\hline \multirow[t]{2}{*}{ Samples } & \multicolumn{2}{|c|}{$\begin{array}{l}\text { Microscope counts } \\
\left(\text { cells } \mathrm{ml}^{-1} \text { ) }\right.\end{array}$} & \multirow{2}{*}{\multicolumn{2}{|c|}{$\begin{array}{c}\text { Plate count before IMB } \\
\left.\text { (CFU ml } \mathrm{ml}^{-1}\right) \\
\text { Other bact. A. salmonicida }\end{array}$}} & \multirow{2}{*}{\multicolumn{2}{|c|}{$\begin{array}{c}\text { Plate count after IMB } \\
\text { (CFU } \mathrm{ml}^{-1} \text { ) } \\
\text { Other bact. A. salmonicida }\end{array}$}} & \multirow[t]{2}{*}{$\begin{array}{r}\text { Colony blot } \\
\left(\text { CFU mI }{ }^{-1} \text { ) }\right. \\
\text { A. salmonicida }\end{array}$} \\
\hline & Total & FA & & & & & \\
\hline Surface & $5.3 \times 10^{6}$ & $6.3 \times 10^{3}$ & $5.6 \times 10^{2}$ & - & 20 & - & ND \\
\hline Water at $10 \mathrm{~cm}$ & $3.3 \times 10^{5}$ & $3.0 \times 10^{2}$ & 33 & - & - & - & ND \\
\hline Water at $3 \mathrm{~m}$ & $3.0 \times 10^{5}$ & $3.9 \times 10^{2}$ & 66 & - & 13 & - & ND \\
\hline Sediment ${ }^{\alpha}$ & $1.3 \times 10^{9}$ & $2.9 \times 10^{5}$ & $4.5 \times 10^{4}$ & - & 20 & - & ND \\
\hline Plankton & $9.0 \times 10^{5}$ & $1.1 \times 10^{4}$ & ND & - & ND & ca 300 & 620 \\
\hline Lice $^{b}$ & ND & ND & $4.4 \times 10^{3}$ & $6.8 \times 10^{3}$ & 93 & $1.1 \times 10^{4}$ & $1.3 \times 10^{5}$ \\
\hline Surface-sterilized lice & ND & ND & $4.8 \times 10^{2}$ & $4.0 \times 10^{4}$ & 3 & $1.6 \times 10^{3}$ & $1.7 \times 10^{3}$ \\
\hline \multicolumn{8}{|l|}{-: No colonies } \\
\hline \multicolumn{8}{|c|}{${ }^{\circledR}$ Results given as cells per gram } \\
\hline \multicolumn{8}{|c|}{${ }^{\circ}$ Results given as cells per louse } \\
\hline
\end{tabular}


the pathogen had been accumulating there for many weeks. In the plankton samples, $A$. salmonicida comprised $1.2 \%$ of the total bacterial counts, which is one order of magnitude higher than the relative abundance observed in the samples from the water column. Despite the fact that $A$. salmonicida was detected by FA in water and sediment samples in numbers well within the detection limits of the immunomagnetic beads method, attempts to isolate the bacterium from the water and sediment samples were unsuccessful. This is in agreement with previous reports, indicating that $A$. salmonicida does not survive indefinitely when it occurs outside of its host (McCarthy 1977, Rose et al. $1990)$.

Aeromonas salmonicida was isolated in high numbers from marine plankton and salmon lice (Table 1). In direct plate counts from homogenized salmon lice, A. salmonicida comprised $60 \%$ of the colony forming units (cfu). Using immunomagnetic beads, however, $A$. salmonicida accounted for 98 to $99 \%$ of the cfu. A. salmonicida has not previously been isolated from animals other than fish (Austin \& Austin 1987). Because the louse can swim between different hosts (Bruno \& Stone 1990), the association of A. salmonicida with salmon lice suggests that the lice may be important vectors in the spread of furunculosis.

Disinfection of the salmon lice in $70 \%$ ethanol reduced the number of bacteria isolated. However, the successful isolation of Aeromonas salmonicida from lice that had been surface-disinfected suggests that a significant proportion of the A. salmonicida cells must have been residing inside the lice, probably in the gastrointestinal tract. Detection of live cells of $A$. salmonicida in the plankton samples also indicates that marine plankton should be considered as a vector of potential importance in the spread of furunculosis.

The isolates were identified as Aeromonas salmonicida subsp. salmonicida based on the API $20 \mathrm{E}$ (Analytical Profile Index Systems S.A., La Balme les Grottes, France) assay.

It is important to underscore the qualitative differences between the 2 detection methods applied in this study. While the immunofluorescence technique provided a useful tool for microscopic enumeration of Aeromonas salmonicida in preserved samples, the isolation techniques based on the use of immunomagnetic beads made it possible to grow the detected bacterium

Responsible Subject Editor: T. Evelyn, Nanaimo,

B.C., Canada on non-selective media. The ability to isolate and grow specific bacteria from environmental samples heavily 'contaminated' with other bacteria is an essential prerequisite for further work with the specific bacteria. Our results show that the often disturbing influence of the background bacterial flora can be reduced substantially by use of this method.

Acknowledgements. This work was supported in part by a grant from the Norwegian Council of Fisheries Research (NFFR). We thank the staff of the fish farm for their valuable collaboration. A. Nylund is thanked for his critical comments on the manuscript.

\section{LITERATURE CITED}

Ahne, W. (1985). Argulus foliaceus L. and Pisciola geometra L. as mechanical vectors of spring viraemia of carp virus (SVCV). J. Fish Dis. 8: 241-242

Austin, B., Austin, D. A. (1987). Bacterial fish pathogens. Ellis Horwood Ltd, Chichester, p. 111-195

Bruno, D. W., Stone, J. (1990). The role of saithe, Pollachius virens L., as a host for the sea lice, Lepeoptheirus salmonis Krayer and Caligus elongatus Nordmann. Aquaculture 89: $201-207$

Cusack, R., Cone, D. K. (1986). A review of parasites as vectors of viral and bacterial diseases of fish. J. Fish Dis. 9: $169-171$

Enger, Ø., Husevåg, B., Goksøyr, J (1989). Presence of the fish pathogen Vibrio salmonicida in fish farm sediments. Appl. environ. Microbiol. 55: 2815-2818

Enger, Ø., Thorsen, B. (1992). Possible ecological implications of the high cell surface hydrophobicity of the fish pathogen Aeromonas salmonicida. Can. J. Microbiol. 38 : $1048-1052$

McCarthy, D. H. (1977). Some ecological aspects of the bacterial fish pathogen Aeromonas salmonicida. Aquat. Microbiol. 6: 299-324

Mulcahy, D., Klaybor, D., Batts, W. N. (1990). Isolation of infectious hematopoietic necrosis virus from a leech (Pisciola salmositica) and a copepod (Salmonicola sp.), ectoparasites of sockeye salmon Oncorhynchus nerka. Dis. aquat. Org. 8: 29-34

Nylund, A., Bjorknes, B., Wallace, C. (1991). Lepeophtheirus salmonis - a possible vector in the spread of diseases on salmonids. Bull. Eur. Fish Pathol. 11: 213-216

Rodrigue, L., Marion, D., Trudel, L., Barthe, C., Lavoie, M. C. (1989). Comparison of method for the evaluation of the oral microbiota of mice. J. microbiol. Meth. 10: 71-82

Rose, A. S., Ellis, E. E., Munro, A. L. S. (1990). The survival of Aeromonas salmonicida subsp. salmonicida in seawater. J. Fish Dis. 13: 205-214

Sakai, D. K. (1986). Electrostatic mechanism of survival of virulent Aeromonas salmonicida strains in river water. Appl. environ. Microbiol. 51: 1343-1349

Manuscript first received: June 12, 1992

Revised version accepted: March 3, 1993 